\title{
Mechlorethamine Oxide Hydrochloride
}

National Cancer Institute

\section{Source}

National Cancer Institute. Mechlorethamine Oxide Hydrochloride. NCI Thesaurus. Code C628.

A nitrogen mustard alkylating agent that causes DNA cross linkages. It is a known carcinogen especially in mice. ( $\mathrm{NCl})$ 